\title{
A Comparative Study of Accounting Standards in Nigeria, United Kingdom and United States of America
}

\author{
Atu,Omimi-Ejoor Osaretin Kingsley; Atu, Oghogho Gina; \\ Atu, Osahenoma Vivian \\ (Aca,Fcma,Acti,Aat, M.Sc(Accounting), M.Sc(Business), Mba(Accounting)Pdg (Comp.Sc); Dipl.Ph.D In View) \\ Lecturer - Department Of Accounting Igbinedion University, Okada. Edo State, Nigeria-West Africa. \\ Post Graduate Student, Igbinedion University, Okada \\ Lecturer - Department Of Accounting Veritas University, Abuja Nigeria-West Africa. \\ Post Graduate Student, Igbinedion University, Okada \\ Audit Manager Atu, Omimi-Ejoor Osaretin \& Co.
}

\begin{abstract}
This study looks into accounting standards as it relates to Nigeria, United Kingdom and United States of America. Standards in Accounting are essential and of utmost importance and as such should not be ignored or neglected in accounting related businesses and literatures. This paper looks at the meaning and reasons for standards, international financial reporting standards (IFRS), comparative analysis of standards in the three countries using variables like tangible assets, research and development, inventories, disclosure of accounting policies, consolidated financial statement, depreciation accounting, reporting financial information by segment and accounting for leases.
\end{abstract}

\section{Introduction}

Accounting theory through the issuance of standards provides direction and guidance on how business enterprise could achieve the goal of proper record keeping, transparency, uniformity, comparability and enhancing public confidence in financial reporting (van tendeloo \& vanstraelen,2005). Thus failure on the part of the firm to apply the requirements of accounting standards would result in inconsistencies, lack of accountability and transparency, distortion in financial reports, which in turn results to poor financial reporting practices and dissemination of accounting information that is of less value to any particular group of users. This is because the preparation and presentation of financial statements lack objectivity, reliability, credibility and comparability, and thus results in fraudulent business practices which subsequently lead to business failure and become devastating on the national economy.

Glautier \& underdown (2001) cited that the need for the imposition of standards arose because of lack of uniformity existing as to the manner in which periodic profit was measured and the financial position of an enterprise presented.

Standards are concerned either with how information might be presented, what information ought to be presented or how assets might be valued. People in every work of life are affected by business reporting, the cornerstone upon which our process of capital allocation is built. An effective allocation process is critical to a healthy economy that promotes productivity, encourages innovation and provides an efficient and liquid market for buying and selling securities, obtaining and granting credit. Conversely, a flawed allocation process supports unproductive practices, denies cost effective capital to companies that may offer innovative products and services that add value, and determines the securities market. Reporting standards play an important role in helping the market mechanism work effectively for the benefit of companies, users and the public.

Hendriksen \& Brenda (1997), noted that although accounting policies are being established on an international level through the International Accounting Standards Committee(IASC), the compliance with its standards is limited to the acceptance of the standards by the representing professional accounting societies and by other organizations and governmental agencies within represented countries.

\section{Meaning Of Standards}

The dictionary meaning of the word "standard" is a level of quality that is normal or acceptable for a particular person or in a particular situation. It's also an acknowledge measure of comparison for qualitative or quantitative value criterion. Ordinarily, the word is used as a norm for comparing two or more items or things. But an accounting standard is not a measure of comparison. The term "accounting standard" refers to accounting guidelines to specific issues in financial accounting and reporting. 
Adedeji (2004) stated that Standards are rules comprising of best practices issued from time to time by a duly empowered body. The standards setting organizations, function by reviewing existing accounting principles and practices and recommend the best through standards.

\section{Objectives Of This Paper}

This objective of this paper is to compare the accounting standards in Nigeria, United States of America and United kingdom.

\section{Reasons For Accounting Regulation And Standards.}

Academics and researchers are in a unanimous agreement that financial reporting practice of a country depends on several factors that include the legal, economic, cultural and historical background of a country. However, the extent of disclosure, its adequacy, relevance and reliability are important financial reporting practices prevalent in a country. Financial reporting is not an end in its self, but is intended to provide information that is used in making reasoned choices among alternative uses of scarce resources in the conduct of business and economic activities. This therefore, recognizes the fact that financial reports exist to satisfy the diverse information needs of numerous users such as the investors, management, employees, government, researchers, and so on. The problem is that firms have incentives to withhold or manipulate information in certain situations (poor performance). This is because the publication of such information imposes both direct and indirect cost on the disclosing firm. Besides the cost of collating, processing, communicating and auditing the information to be published, the position of the disclosing firm may be damaged when such information is used by competitors, government agencies, trade unions, clients or suppliers. Mandatory disclosures, therefore make it binding upon firms to reveal information regardless of its realization, provided that they are properly enforced. Consequently, while some countries use coercive means, through enforcement and punishment for non-compliance in order to induce application of standards, other countries make it voluntary as a guide to best accounting practices.

According to Porwal (2006), Standardization has helped to achieve the following objectives:

It has helped to reduce wide judgmental intuition and discretion, which has reduced the work of the external auditor considerably.

It allows for a considerable level of consistency in the application of accounting policies, which has helped to strengthen comparability.

The standard setting process has helped to provoke a high level of research and discussion among members of the profession and this has awakened the profession from its slumber. Provide information on the financial strength and performance of the organization to users of accounting information. Though standards are not legally enforceable, but directors are required to disclose in the notes whether the accounts have been prepared in accordance with the relevant statement of accounting standards issued by the Nigerian accounting standard board.

\section{INTERNATIONAL FINANCIAL REPORTING STANDARDS.}

The International Financial Reporting Standards (IFRS) started with the formation of the International Accounting Standards Committee in 1973 as a result of an agreement by professional accountancy bodies of major countries (United Kingdom and Ireland, United States, Australia, Canada, France, Germany, Japan, The Netherlands and Mexico) to develop a set of accounting principles across the globe. In its early days, the IASC were aimed at promoting best practices in the preparation of financial statements while permitting different treatments for given transactions and events.

Aghator \& Adeyemi (2009) stated that with the dawn of globalization and increasing demand for transparent, comparable financial information in the markets, the IASC was restructured in the year 2001 by creating the International Accounting Standards Board (IASB), among other changes. The IASB is responsible for developing, in the public interest, a single set of high quality, comprehensive and enforceable global accounting standards that require transparent and comparable information in general purpose financial statements and other financial reporting to help participants in the various capital markets of the world and other users of the information to make economic decisions.

Consequently the IASB has since inception issued a number of IFRS and interpretations. In pursuance of its objectives, the IASB cooperates with national accounting standards setters to achieve convergence in accounting standards in the world. IFRS are developed through an international due process that involves accountants, financial analysts and other users of financial statements., the business community, stock exchanges, regulatory and legal authorities, academia and other interested individuals and organizations from around the world. This due process is conducted by the IASB, which has complete responsibility for all technical matters including the publication and issuance of standards and interpretations. 
Aghator \& Adeyemi (2009) opined that International Financial Reporting Standards (IFRS) refers to a series of accounting pronouncements published by the International Accounting Standards Board to help preparers of financial statements, throughout the world, produce and present high quality, transparent and comparable financial information. Currently, financial statements prepared for reporting in Nigeria are drawn up in accordance with requirements laid down by CAMA and pronouncements issued by the Nigeria Accounting Standard Board. If IFRS were to adopted fully in Nigeria, Nigeria reporting entities would be using the same frame work as their peers worldwide, which would enhance the relevance of their reports in the international arena. In recent times, we have seen many countries in Africa as well as in European Union countries adopting IFRS as the financial reporting framework. The Financial Accounting Standard Board of the United States has already agreed a roadmap with the IASB on the convergence of united states standard and IFRS. This is in recognition by large economies of the need to have high quality standards that are used consistently around the world to improve the efficiency with which capital is allocated.

\section{Accounting Standards In Nigeria.}

The Nigerian Accounting Standard Board (NASB).

The Nigerian accounting standard board which is now replaced with Financial Reporting Council (FRC) was established in September 1985 with the following objectives:

1. To formulate and publish in the public interest, accounting standards to be observed in the preparation of financial statements and to promote the general acceptance and adoption of such standards by preparers and users of financial statements.

2. To promote and sponsor legislation, when necessary in order to ensure that standard developed and published by the board receive nation-wide acceptance, adoption and compliance.

3. To review from time to time, the standards developed by the board in the light of changes in the social, economic and political environment.

statement of Accounting Standards in Nigeria.

The procedure for the development of a statement of Accounting Standard is time consuming, painstaking and requires the involvement of members of council and the public at large. Statements of Accounting Standards are standards used by management of companies in the preparation of financial reports. Independent auditors are responsible for ensuring that the standards are applied properly by management and that the information reported to the public fairly reflects the substance of the company's business activities.

Advantages of statement of accounting standards includes:

1. Reduction or elimination of variations in methods used in preparation of final accounts.

2. It oblige companies to disclose the accounting bases used in the preparation of financial reports.

3. It provides a local point for debate and discussion about accounting practice.

\section{Accounting Standards In The United Kingdom.}

Generally Accepted Accounting Principles (UK)

The generally accepted accounting principles (GAAP) in the UK are the overall body establishing how company's accounts must be prepared in the United Kingdom. The accounting standards derived from a number of sources, the major standard setter is the Accounting Standard Board (ASB), which issues standards called financial reporting standards (FRS). The ASB is part of the Financial Reporting Council, an independent regulator funded by a levy on listed companies, and it replaced the Accounting Standard Committee .The principal legislation governing reporting in the UK is laid down in the company's act 2006, which incorporates the requirement of European law. The companies act sets out certain minimum reporting requirements for companies.

From the year 2005, the reporting framework changed as a result of European law requiring that all listed European companies report under international financial reporting standards. In the United Kingdom, companies which are not listed have the option to report either under IFRS or under UK GAAP. Dumontier \& Raffoumier (1998)

\section{United States Accounting Standards}

Generally Accepted Accounting Principles (United States.)

In the aftermath of the enron and worldcom crisis and subsequent developments with the Sarbanes oxley act, the Financial Accounting Standard Board (FASB) in United States and the standards they issue are in the spotlight. In the US, Generally Accepted Accounting Principles commonly abbreviated as GAAP are accounting rules to prepare, present and report financial statements for a wide variety of entities including public and private companies. 
Similar to many other countries practicing under the common law system, the United States government does not directly set Accounting Standards, in the belief that the private sector has better knowledge and resources. Currently, the Financial Accounting Standard Board (FASB) is the highest authority in establishing generally accepted accounting principles for public and private companies, as well as nonprofit making entities. For local and states government, GAAP is determined by the Governmental Accounting Standard Board (GASB), which operates under a set of assumptions, principles and constraints different from those of standard private sector GAAP. Financial reporting in federal government entities is regulated by the Federal Accounting Standards Advisory Board (FASAB). The US GAAP provisions differ from the International Financial Reporting Standards, though the former security and exchange commission chairman chris cox has sets out a timetable for all US companies to drop the GAAP and switch to IFRS.

\section{Methodology Of This Paper}

The research method adopted in this paper was secondary. This includes observations, related materials and documented literatures

\section{Accounting Standards In Nigeria, United Kingdom And United States.}

According to Van der tas (2008), The International Accounting Standards Committee (IASC) and countries like the USA, UK and Nigeria are some of the countries which have promulgated accounting standards. Following is an overview of the different aspects of accounting standards in these countries and the IASC:

\section{STANDARD -SETTING ORGANISATION:}

USA: Financial Accounting Standard Board (FASB) is the only body solely in charge of issuing standards since 1973. The seven members of the FASB are selected from diverse backgrounds.

UK: The Accounting Standards Board (ASB) is comprised of nine members drawn from different user-groups Nigeria: The Nigeria Accounting Standards Board (NASB) is the body solely in charge in charge of issuing standards since 1985

IASC: The committee main function is to issue standards for adoption by its members (professional bodies) in 80 Countries.

\section{CURRENT STATUS OF THE STANDARDS:}

USA: 137 statements of financial accounting standards and six statements of financial accounting have been issued, besides 42 interpretations and many technical bulletins (TB).

UK: 26 Statements of standards accounting practice were issued by the ASC. The ASB has issued reporting standards.

Nigeria: 32 statements of accounting standards (SAS) have so far been released. The exposure draft may be modified in the light of the comments received before it is issued as a statement of accounting standards.

IASC: 40 accounting standards have thus far, been issued.

\section{NATURE OF STANDARDS:}

USA: All the standards are mandatory; they have substantial authoritative support of the SEC.

UK: All the standards are mandatory.

Nigeria: All the standards are mandatory

IASC: All the standards are recommendatory. It's for the standard setting body of a country concerned to adopt the standards (with or without amendments)

\section{CONCEPTUAL FRAMEWORK OF ACCOUNTING:}

USA: The conceptual framework project has been completed.

UK: The ASC had adopted the framework prepared by the IASC (1989) but the ASB which replaced the ASC has issued the statements of principles on objectives and qualitative characteristics.

IASC: In April, 1989, a framework for the preparation and presentation of financial statements has been issued.

\section{Comparison Of Nigeria, United Kingdom And United States Accounting Standards}

It is logical to come to the opinion that accounting standards still differ extensively from country to country. Individuals among these countries are proud and developed around their own accounting rules. There are many factors that can explain why accounting standards are not the same everywhere. This includes external environment and cultural factors in countries. Another factor is legal systems that focus and operate around statute law. Healy \& Wahlen (1999) expanded on this and illustrate these differences on tangible assets, research and development, inventories, accounting policies, consolidated financial statements, depreciation accounting, reporting financial information by segment, accounting for leases in the U.K, U.S.A and Nigeria. 
TANGIBLE ASSET:

UK: Tangible fixed assets should initially be measured at cost. Revaluation is permitted of individual classes of such assets. All tangible fixed assets other than investment properties must be depreciated using the common approach i.e. straight line method. SSAP 19 requires investment properties to be shown in balance at open market value and any change in the value is to be taken to an investment revaluation reserve.

USA: They believe that the financial statement carrying values of property, plant and equipment are not increased on the basis of appraisals or changes in prices because those events are not transactions. The assets is depreciated using the straight-line method where one allocated the cost or other basic value of tangible capital assets, less salvage (if any) over the estimated useful life.

Nigeria: The standard deals with accounting for property, plant and equipment under the historical cost concept. This standard is to provide a guide for the uniform and acceptable methods of determining and reporting depreciation on items of property, plant and equipment whether such items are stated at their historical costs or revalued amounts.

\section{RESEARCH AND DEVELOPMENT:}

UK: Development expenditure may be capitalized in special circumstances. SSAP 13 on research and development requires research to be written off as incurred but allows capitalization of development costs in defined circumstances. Disclosure is required of research and development costs written off and of movements in unamortized deferred development costs.

USA: All expenditures are charged to earnings as outlined in FSA2

Nigeria: This standard prescribes the accounting treatment for research and development costs and is expected to provide an acceptable and uniform accounting practice for entities that engage in research and development activities whether for product/service development or as a grant to research entities for related purposes.

\section{INVENTORIES:}

UK: SSAP 9 on stock (inventories) states that inventories should be valued at lower of cost and net realizable value but LIFO method cannot be used as a measure of cost,

USA: There is no particular difference in theory between UK and USA except that LIFO is allowed for inventory valuation for tax purposes.

Nigeria: This standard prescribes the accounting treatment for inventories under the historical cost system. A primary issue in accounting for inventories is the amount of cost to be recognized as an asset and carried forward until the related revenues are recognized.

\section{DISCLOSURE OF ACCOUNTING POLICIES:}

UK: Presentation of comparative financial statements is required.

USA: Presentation of comparative financial statements required for public companies (SEC regulations) not required for private companies.

Nigeria: This standard prescribes the specific principles, bases, conventions, rules and practice adopted by an enterprise in preparing and presenting financial statements.

\section{CONSOLIDATED FINANCIAL STATEMENT:}

UK: Consolidation is required if control is exercised by the power to nominate a majority of board of directors.

USA: Consolidation not permitted without ownership of more than half of the equity interest.

Nigeria: Holding company owns majority of equity capital but less than half of voting stock

\section{DEPRECIATION ACCOUNTING:}

UK: Disclosure requires individually for each major class of depreciable asset. (In addition disclosure is required of all movements during the year for individual classes of fixed assets).

USA: Disclosure of such information not required individually for each major class of depreciable asset,

Nigeria: This standard is to provide a guide for uniform and acceptable methods of determining and reporting depreciation on items of property, plant and equipment whether such items are stated at their historical costs or revalued amounts.

\section{REPORTING FINANCIAL INFORMATION BY SEGMENT:}

UK: Disclosure of segment sales and profits before tax are made in Directors reports, details of assets employed and pricing are not required to be disclosed.

USA: Disclosure of profit after allocation of common costs and capital employed required for each class of business. 
Nigeria: This statement establishes acceptable guide for: classification by segment in terms of business and locations; determining what constitutes material segment and formats for the presentation of financial statements by segments.

\section{ACCOUNTING FOR LEASES:}

UK: Requires both lessees and lessors capitalize that finance lease.

USA: Requires that finance leases be capitalized for both lessees and lessors.

Nigeria: This standard is to ensure that published financial statements contain sufficient information about lease transactions to make it possible for users of such statements to determine the effects of lease commitments on the present and future operations of the reporting enterprises and to ensure uniform disclosure of terms and classes of leases in financial statements.

\section{Conclusion}

Accounting Standards are guidelines which define how companies have to display transactions and events in their financial statements and are not purely technical rules but they are the outcome of highly political processes. This means that there are different actors who come into contact with or are influenced by accounting standards for example accounting firms, financial analyst, employees, managers, etc. all these actors might have different opinion and interest about what an accurate and useful accounting standard is and therefore might have different incentives in the production and diffusion of accounting standards. The importance of compliance with the requirements of accounting standards is that it enhances transparency, accountability, standardization, uniformity and comparability which in turn enriches the quality of decision of the users and helps in proper allocation of resources in an economy. Glaulier \& Underdown (2001)

The enactment of NASB Act of 2003, has to some extent not only affected compliance with the requirements of SAS by quoted firms in Nigeria but has also reduced the variability in the application of the standards among firms. The statement of accounting statements which purport to be complimentary to the international accounting standards are outdated and hence, the need to be updated since developing accounting standards involves substantial cost, time consuming and involves wide consultations.

Despite UK accounting system is moving closer to US GAAP and IAS, she still wants the true and fair concept to remain valid. There has been a vast improvement in the quality of financial reporting in the UK but still out of step when you compare UK to other developed countries especially in areas such as goodwill. There has been quite a big change in US accounting, until very recently the US has operated in an isolated situation from the rest of the world especially when related to accounting policy making bodies. However there is now an intertwined action by the US on accounting issues making US accounting difficult to separate from the rest of the world and continues to explore and develop further improvements in the accounting profession.

\section{Recommendations}

The following points are recommended according to Glaulier \& Underdown (2001):

1. Accounting standards should be reviewed in the light of new development (technical, financial, legal, economical and fraud) and international practices. The Accounting standards should harmonize not only with international standards but with other applicable corporate and taxation legislation. To incorporate social justice, environmental issues, economic reforms and social context, vis-à-vis to make professional managers and directors more accountable to shareholders and other stakeholder, accounting standards should narrow the choice of alternative accounting practices that make fair disclosure of accounting and financial information. In the light of the above, it is suggested that fair disclosure, honest actions, independence, materiality and vision to sustainable development of corporate and society should be woven together with vibrant precise accounting standards.

2. The recent accounting scandals relating to firms like Enron and Worldcom have shown that accounting data is subject to manipulation. Though this insight may not be new, it nevertheless raises public attention towards serious frictions in the information gathering process of public capital markets. As long as these frictions are related to fraudulent misrepresentation in the financial statements only, our paradigm of informational efficient capital markets might not be seriously challenged. In this case, the society should focus on improving the enforcement of accounting rules. As it has been done in the aftermath of the Enron accounting scandal.

3. We also recommend that the NASB should adopt international Accounting Standards, especially because of the globalization of economies. Doing this with or without modification would not compound the problem but rather improve the quality of financial statements and financial reporting in Nigeria. The Nigerian Accounting Standard Board (NASB) should make audit firms not only responsible but also accountable for their clients non-applicable of accounting standards. This can be achieved through proper monitoring, 
enforcement and penalties for non-application. This, it is believed, would not only enhance quality and professionalism in audit practice but also solve the problems of financial reporting in Nigeria.

\section{References}

[1]. Adedeji B.A. (2004): Accounting Theory and Regulatory Framework; Lagos Nigeria.

[2]. Aghator G.E \& Adeyemi B. (2009): Comparative Study of Accounting Standards in Nigeria, United Kingdom and United States of America. An Unpublished Term paper presented in Igbinedion University, Okada.

[3]. Dumontier, P. \& Raffournier B (1998): Why firms Comply Voluntarily with IAS; An Empirical Analysis with Swiss Data: Journal of International Financial Management \& Accounting. Vol. 9

[4]. Glaulier M. \& Underdown B. (2001): Accounting Theory and Practice; London, FT-prentice Hall $7^{\text {th }}$ edition. ELBS

[5]. Hendriksen E.S. (1982):Accounting Theory(revised edition). Richard D Irwin Inc

[6]. Hendriksen E.S \& Breba M.F. (1997):Accounting Theory, Irwin, Homewood 111

[7]. Healy P.M. \& Wahlen J.M. (1999): A review of the earning management literature and its implications for standard setting. Accounting Horizins, Volume 13, No.4

[8]. International Accounting Standard Board (2002) Exposure Draft: Improvements to international Accounting Standard (on line) Available on: hhtp://www.iasc.org.uk

[9]. NASB (1991): Nigerian Accounting Standard Board; Statement on Accounting Standards, university of Lagos press.

[10]. NASB (2003): Nigeria Accounting Standard Board Act.

[11]. Powal S.L. (2006): Accounting Theory, An Introduction $8^{\text {th }}$ Edition; Tata McGraw Hill Publishing Co. Ltd. New Delhi, India.

[12]. Van der Tas L.G. (2008): Measuring Harmonisation of Financial Reporting Practice; Accounting and Business Research.

[13]. Van tendeloo, B \& A. Vanstraelen(2005): Earnings Management under German GAAP versus European Accounting Review.

[14]. www.lasb.org

[15]. www.oracle.com/fr/application/newsletter/wpnormESIASmars03.pdf

[16]. www.google.com/unitedstatesaccountingstandards 